\title{
Spatial Absorbency Assessment for Sustainable Land Development ${ }^{5}$
}

\begin{abstract}
Sustainable land use development requires a smart decision-making process based on appropriate spatial design patterns. However, the pro-investment policy of many municipalities often results in disproportions between the demand and supply of investment areas, which means that spatial development is not realized in a sustainable way. In order to avoid the overconsumption of land for investment purposes, central government in Poland introduced a requirement to assess land balance, which includes the calculation of spatial absorbency at the level of local urban planning. The aim of this work is to develop the concept of spatial absorbency assessment. In order to select best practices, document reviews of local spatial policies in Kalisz, Łódź, Toruń and Gdańsk were performed. Based on the review, a method for spatial absorbency assessment was presented. The applicability of the proposed solution is presented by its use on the case of the Racibórz municipality. The visualization shows what kind of geoinformation is required to perform an assessment by means of the developed method. The results of the calculations present the final feedback that is received by local authorities. The work was carried out using ArcGIS software. The obtained results may constitute the basis for further multi-dimensional analyses as part of sustainable land development planning at the local level.
\end{abstract}

Keywords: absorbency, carrying capacity, urban planning, spatial development

Received: 13 November 2019; accepted: 17 January 2020

(C) 2020 Authors. This is an open access publication, which can be used, distributed and reproduced in any medium according to the Creative Commons CC-BY 4.0 License.

1 Wrocław University of Environmental and Life Sciences, Student Scientific Organization of Spatial Management PUZZLE, Wrocław, Poland, email: brozanoemi@gmail.com

2 Wrocław University of Environmental and Life Sciences, Student Scientific Organization of Spatial Management PUZZLE, Wrocław, Poland, email: kabirnbaum@gmail.com

ORCID ID: https://orcid.org/0000-0002-5833-9336

3 University of the Basque Country, Department of Financial Economy II, Vitoria-Gasteiz, Spain, email: david.garciac@ehu.eus

ORCID ID: https://orcid.org/0000-0003-4819-7116

4 Wrocław University of Environmental and Life Sciences, Institute of Spatial Management, Wrocław, Poland, email: jan.kazak@upwr.edu.pl

ORCID ID: https://orcid.org/0000-0002-1864-9954

5 The research was funded by the Wrocław University of Environmental and Life Sciences 


\section{Introduction}

Current challenges in land development and management, such as uncontrolled urban sprawl [1], urban ageing [2, 3] or adaptation to climate change [4, 5], force local decision makers to search for more sustainable approaches in land use planning. The shift from a central land development planning system to a decentralised one in the early 1990s in Poland involved individual investors taking more independent actions. Unfortunately, this did not result in the implementation of the most suitable solution according to local resources and needs in every situation [6, 7]. According to the legal framework in Poland [8], the document expressing spatial policy on a local scale is a study of conditions and directions of the spatial development of the municipality. This document should set the framework of spatial development patterns and guarantee the sustainable development of the municipality. However, studies conducted in Poland have proven that the spatial planning documents existing at the beginning of this decade were not effective enough to guarantee sustainable development at the local level $[9,10]$. Local authorities are often tempted by potential profits related to attracting new citizens, and they do not calculate the costs of new urban development well [11]. As a result, expenses may exceed profits [12,13] and new land development is a burden for the municipality. That is why it can be regarded as constituting an unsustainable action in economic terms. Similar situation can be observed in environmental terms, where new urban development degrades valuable environmental resources [14-16], or social, where migration can cause social conflicts [17]. The level of imbalance between supply and demand in land use planning was highlighted by the authors of the report Analysis of the Status and Conditions of Spatial Planning Work in Municipalities at the end of 2017. According to the information included in the report, areas designated for housing purposes in the whole country would enable the accommodation of approximately 76 million people - double the current population. In order to solve the problem of this imbalance in land development, a new element in local spatial policy became obligatory. In October 2015, an amendment to the act on spatial planning and development was introduced, which obliges municipalities to prepare the area's balance including calculation of spatial absorbency [18]. Spatial absorbency has to be calculated separately for (1) areas with urban structure (AUS) and for (2) areas designed in master plans as housing areas (AMP). The legal framework for estimating spatial absorbency is Article 10 paragraph 5 of the Act of March 27, 2003 on planning and spatial development [8]. This new regulation is in line with academic guidelines that land use change monitoring is defined as a task of a local administration [19]. Nonetheless, the new regulations did not define exactly how spatial absorbency should be calculated. Therefore, there is no universal way to assess spatial absorbency. Unfortunately, in some municipalities, they do not rely on clearly defined approaches and this may lead to it being ineffective. However, based on the advantages of using land administration systems and geographic information systems (GIS) which can effectively support sustainable development implementation [20-22], the 
aim of this study is to propose a spatial absorbency framework which would allow local authorities to fulfill new legal requirements. The paper is structured as follows: materials needed to conduct the study are discussed in section 2 , method in section 3 , the review of existing solutions in section 4 , the proposed methodological framework for spatial absorbency calculations in section 5, the application of the proposed method in section 6, and, finally, discussion and conclusions in section 7.

\section{Materials and Study Area}

The materials used in the study were five studies of conditions and directions of spatial development of municipalities for Kalisz, Łódź, Toruń, Gdańsk and Racibórz as well as master plans from the Racibórz municipality.

The study area for the application of the developed framework is the Racibórz municipality. It is an urban municipality located in Silesian region. The area of the Racibórz municipality is approximately 1460 ha and the spatial policy of that municipality was adopted in 2013 [23].

\section{Method}

The study is divided into two parts. The first part is based on the review of existing land development documents. It allows us to compare currently used approaches in spatial absorbency calculations. The review was carried out based on four studies of conditions and directions of spatial development of municipalities for Kalisz, Łódź, Toruń and Gdańsk (Fig. 1). This part is presented in section 4.

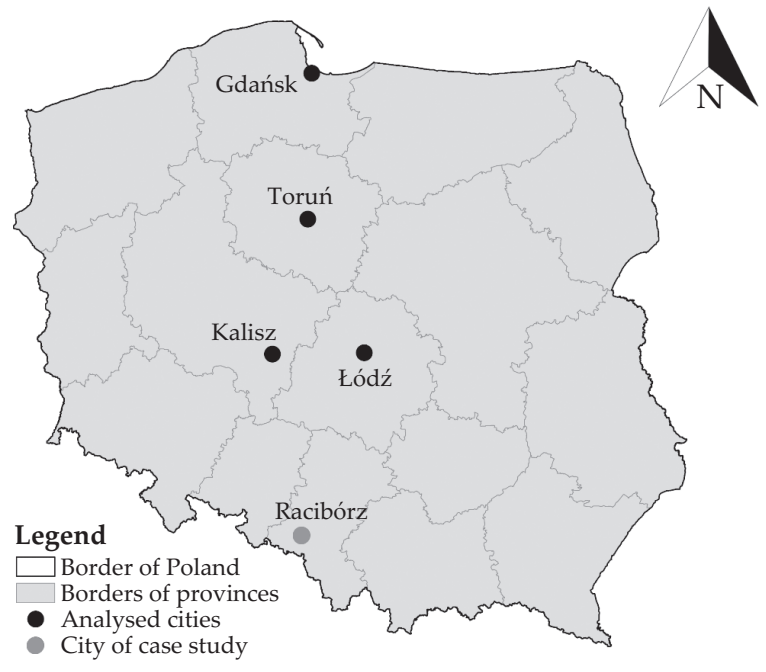

Fig. 1. Location of analyzed cities 
Based on the review of existing approaches in practice of land development, a novel method for spatial absorbency is proposed in section 5. The developed approach uses GIS which organizes all stages of data processing. Presentation of the applicability of this method is shown on the case of Racibórz municipality in section 6.

\section{Spatial Planning Documents Review}

The following subsections present a review of studies of the conditions and directions of spatial development of municipalities (spatial policies; SP) of Gdańsk, Łódź, Toruń and Kalisz.

\subsection{Spatial Policy of Gdańsk}

The definition of the concept of absorbency highlighted in the spatial policy of Gdańsk refers to the maximum value [24]. As a source of data necessary to calculate the absorbency of housing-service areas, the parameters of housing, housing-service and service development as set out in master plans (MP) or in spatial policy (in areas that do not have a valid MP) were taken. The law does not introduce what qualifies as areas with an urban structure. Therefore, seven criteria were set to help define the boundaries of AUS. Not all of them have to be done simultaneously. Residential, service, industrial and harbor areas were included. This represents 55\% of the area of the whole city. Spatial capacity for housing, services and harbor-industrial was calculated based on formula:

$$
S_{p c}=A_{n} \cdot \mathrm{IBI}_{\max } \cdot x \quad\left[\mathrm{~m}^{2}\right]
$$

$S_{p c}$ - spatial capacity,

$A_{n}$ - net area $\left[\mathrm{m}^{2}\right]$,

$\mathrm{IBI}_{\max }$ - indicator of maximum buildings intensity,

$x$ - indicator of converting the total area into usable.

Dual areas were calculated based on proportions contained in master plans.

\subsection{Spatial Policy of Łódź}

In the spatial policy of Łódź [25], an estimation was made for residential, industrial and commercial areas. Three possible development scenarios were presented: lack of spatial activities, maximum building coverage - low standard of living and implementation of the strategy of returning to the city center - raising the standard of living. The capacity of the reserves was determined on the basis of the following indicators: area of land intended for development, average population density 
and average usable floor space per apartment. The following areas were taken into account: multi-family housing, intensive single-family terraced, single-family medium-intensity, single-family low intensity.

The spatial absorption in existing master plans, expressed in the usable area of the building, was calculated on the basis of the maximum building and land development indicators, which result from the provisions of the existing local plans. In both cases, no formulas which might constitute the basis for the calculation were presented, which reduces the transparency of evaluations.

\subsection{Spatial Policy of Toruń}

The basis for estimating the absorbency of undeveloped multi-family residential areas was the number of areas designated for new buildings, building intensity included in the local plans or average building intensity indicators, the percentage share of the built-up area referring to the area of the construction plot and other local conditions. The basis for estimating the spatial absorption of built-up single-family residential areas was the analysis of separate construction plots or the expected number of new plots.

The general area of the different types of lands was presented, where it is possible to locate new buildings together with specifying the number of plots included in it. Other indicators were not included in the presentation of absorbency [26]. As in the case of Łódź, in section 4.2, there is no clearly defined mechanism for calculating spatial absorption.

\subsection{Spatial Policy of Kalisz}

Records of master plans and spatial policy [27] (in areas where there is no applicable local plans) were taken as the data source for the absorbency estimation. Built-up areas with access to a public road, equipped with technical infrastructure (water and sewage system) with accompanying recreational green areas were classified as areas belonging to the AUS. To calculate the usable area of residential buildings, parameters such as: the average area of a new plot and the average usable area of a new apartment were adopted. The quotient of the free spaces(gaps) between buildings and the average area of new plots was calculated. It was expressed in the number of construction plots.

$$
U_{r b}=\frac{U_{n a}}{A_{n p}}
$$

$U_{r b}-$ usable floor area of residential buildings $\left[\mathrm{m}^{2}\right]$,

$U_{n a}-$ undeveloped area intended for housing $\left[\mathrm{m}^{2}\right]$,

$A_{n p}$ - average area of new plots $\left[\mathrm{m}^{2}\right]$. 
The product of the number of construction plots and the average usable area was then calculated, which gave the necessary usable floor space for the apartments.

$$
A=U_{r b} \cdot A_{u}
$$

$A$ - usable floor space of flats $\left[\mathrm{m}^{2}\right]$,

$U_{r b}-$ usable floor space of residential buildings $\left[\mathrm{m}^{2}\right]$,

$A_{u}$ - average usable area $\left[\mathrm{m}^{2}\right]$.

\section{Methodological Framework for Spatial Absorbency Calculations}

The proposed method of estimating spatial absorbency is presented in Figure 2. For absorbency 1 of the Racibórz commune, raster data were obtained from the SCDSD included on the website of the Municipal Office in Racibórz. These data have been vectorised using ArcGIS 10.4.1.

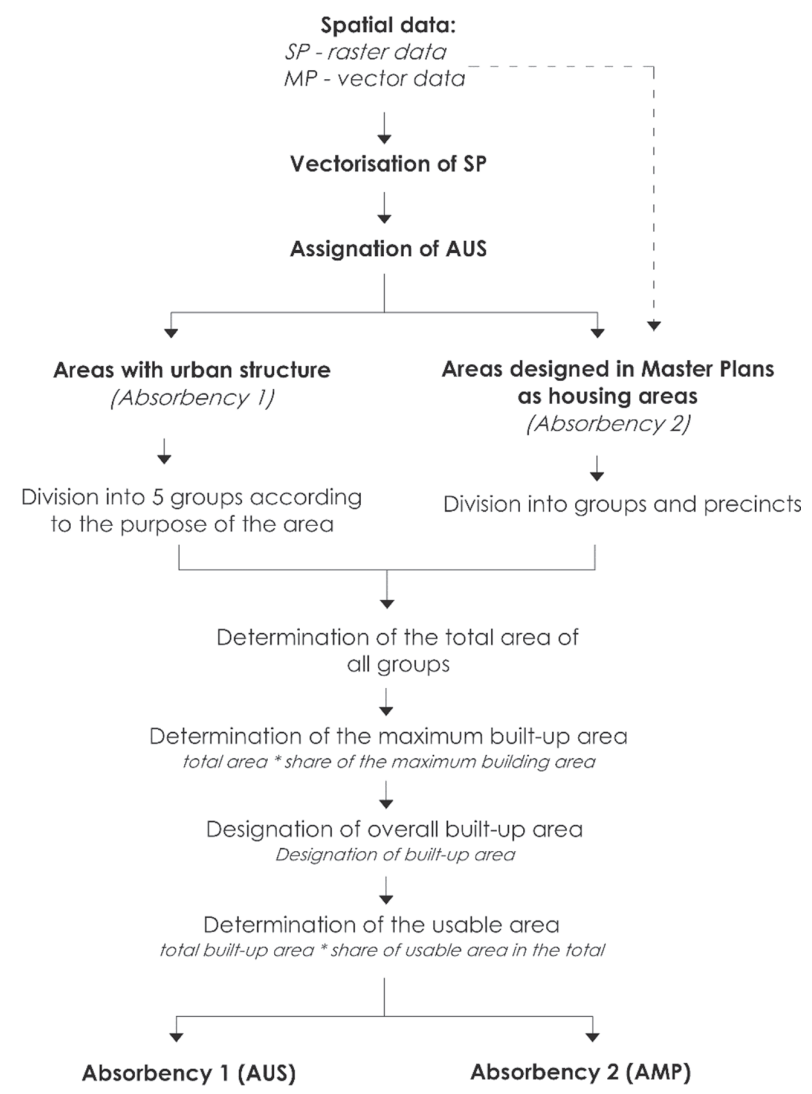

Fig. 2. The process of estimating spatial absorption in the commune of Racibórz 
In the Act [8], there is no definition of the term spatial absorbency. Hence, for the purposes of the study, a definition of absorbency was adopted and says it is the potential maximum usable area of the buildings with an assigned function that may arise in a given area.

To determine a compact and fully developed functional and spatial structure, criteria that must be met were established. It was assumed that the areas can be included in the AUS if they fulfill at least $75 \%$ of the guidelines. Those criteria are:

- access to a public road,

- access to the technical infrastructure network, at least: power network, water supply network,

- existing division into plots,

- existing buildings,

- surrounded by built-up areas, at least $75 \%$ of the neighborhood.

Areas fulfilling mentioned above assumptions have been vectorised with divisions into functions: single-family housing, multi-family housing, services, industrial and planned development.

To determine the absorbency 2, it was necessary to designate the total area of AMP. The coverage data of the master plans were downloaded by Web Future Service to ArcGIS 10.4.1. software. Then, the area of residential lands designated for development was determined.

\section{Application of the Proposed Method}

For the analysis of spatial absorbency, it was assumed that spatial capacity by definition is the maximum value. Buildings with flat roofs will pose maximum value for areas of residential housing, services and industrial because there is no surface which is out of service. Therefore, $100 \%$ of the usable area of buildings was adopted as a usable area. The second assumption was for multi-family housing, where the usable area in general was $100 \%$. This is possible in houses with common areas outside the building (galleries).

According to the method, choosing which areas can be built-up from all categories was necessary. Figure $3 \mathrm{~b}$ presents the results of this. The next step was to classify which areas belong to AUS and divide them into groups (Fig. 3c) according to spatial policy (Fig. 3a). Figure 3d shows built-up areas in AMP which is the basis on which to specify absorbency 2 according to Article 10 paragraph 5 of the Act of March 27, 2003 on planning and spatial development [8].

After completing all the stages described in the method, the results were obtained for AUS and AMP. The final summary of the estimated absorption values is presented in Table 1. 
a)

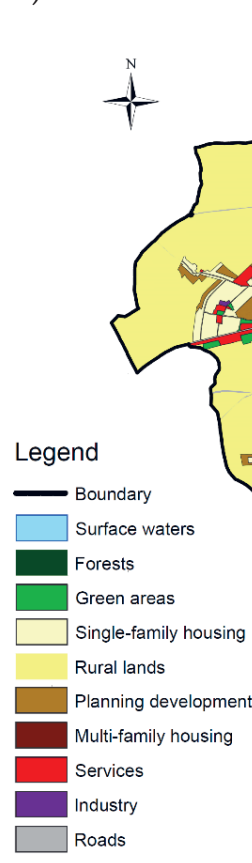

c)

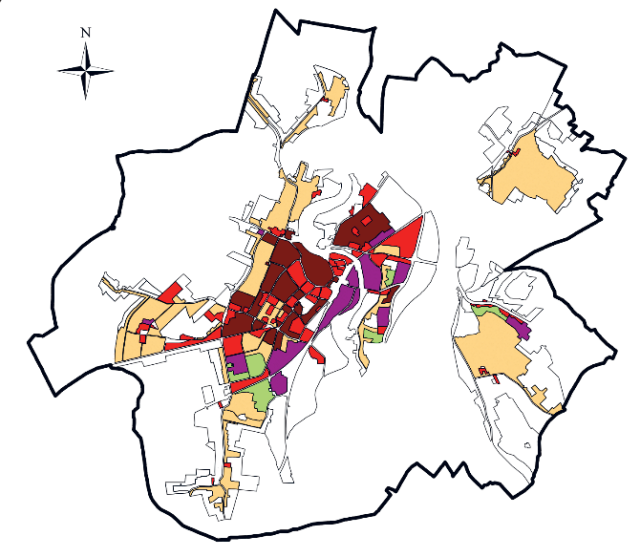

Legend:

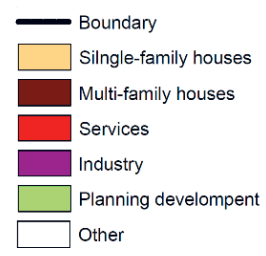

b)

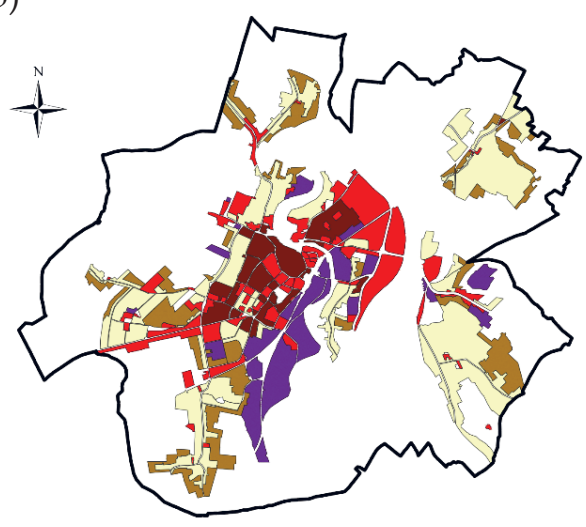

Legend

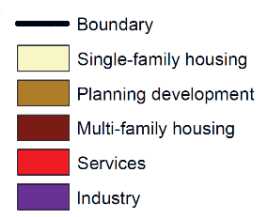

d)

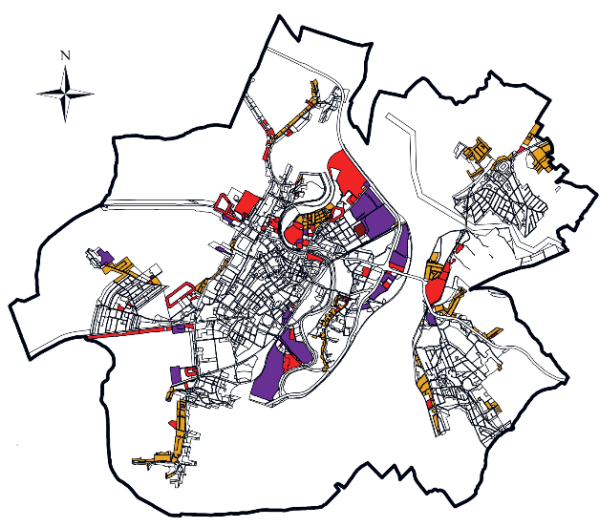

Legend

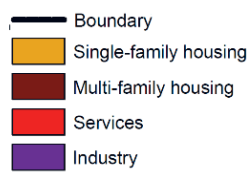

Fig. 3. Vectorised spatial policy (a); selected built-up area (b); AUS area divided into groups (c); selected AMP areas (d) 
Table 1. Summary of the estimated spatial absorbency

\begin{tabular}{||l|c|c||}
\hline \multirow{2}{*}{$\begin{array}{c}\text { Type of land use area } \\
{[-]}\end{array}$} & \multicolumn{2}{|c|}{ Usable area of buildings } \\
\cline { 2 - 3 } & $\begin{array}{c}\text { Absorbency 1 (AUS) } \\
{\left[\mathrm{km}^{2}\right]}\end{array}$ & $\begin{array}{c}\text { Absorbency 2 (AMP) } \\
{\left[\mathrm{km}^{2}\right]}\end{array}$ \\
\hline \hline Single-family housing & 1.035 & 1.730 \\
\hline Multi-family housing & 0.644 & 0.068 \\
\hline Planned development & 0.096 & - \\
\hline Services & 2.152 & 2.788 \\
\hline Industrial & 0.792 & 2.630 \\
\hline SUM & 4.719 & 7.126 \\
\hline
\end{tabular}

Spatial absorption in the area of a compact and fully developed functional and spatial structure is $4.719 \mathrm{~km}^{2}$. Absorption for other areas is $7.126 \mathrm{~km}^{2}$. A difference between the absorption capacity between different types of land use can be noticed. This is due to the disproportion of the size of the area allocated to these functions.

\section{Discussion and Conclusions}

Sustainable land development is strongly influenced by the investment activity of Polish cities $[28,29]$. The final situation of urban development significantly impacts on local socio-environmental systems [30-32]. In order to balance the supply and demand of real estate, different tools can be used. One of them could be to monitor spatial absorbency assessment which is still a new element in Polish land management practice. As Jawecki et al. [33] stated, new legal regulations have an influence on the assessment methods of the physical aspects of a built environment. Therefore, such methods are also required in the case of spatial absorbency. Due to the existing regulations, municipalities can realize this obligation in different ways, without really supporting their decisions in the land development process. However, there are already some studies as to how spatial calculations can support planning by assessing the potential economic implications of spatial policies and master plans [34,35]. Taking into account the current trend of incorporating geoinformation into communication and management tools [36], the spatial absorbency calculations could constitute an element of development planning tools, which are used to increase the effectiveness of urban planning decisions [37]. The element of spatial calculations that is presented in this paper can be defined differently in other domains. Spatial absorption is treated differently by urban planners, ecologists and economists $[38,39]$. However, regardless of the scientific background of all of these approaches, their aim is to help answer the question of how much anthropopressure can be handled by the socio-environmental system in order to guarantee a high level 
of quality of life for citizens [40] and support integrated sustainable development approaches in local governance [41].

The developed method enabled the calculation of the spatial absorbency of areas in the Racibórz municipality. By comparing absorbency with potential demand for new housing areas, decision makers will be able to assess if there is a high possibility that new master plans are needed. The workflow of calculations would enable any other municipality to apply it in their own case. The proposed solution fits the current direction of developing decision support systems for sustainable local development $[42,43]$. The designed approach relies on generalized assumptions of the average consumption of spatial resources, and in this sense it is similar to fundamental analysis [44], where small variables are neglected in order to present general trends and approximate benchmarks. The intention of this work is to initiate a discussion as to how to assess spatial absorbency and share the advantages and disadvantages of different approaches. Based on the conclusions from the Analysis of the Status and Conditions of Spatial Planning Work in Municipalities report at the end of 2017, it seems that there is an urgent need to establish universal requirements for municipalities to follow in order to balance supply and demand for land for future development to ensure sustainable development. Due to the national legal framework, the proposed solutions might be incorporated directly in Poland, however, in case of similar regulations or implementation of best practice, spatial absorbency assessment could also be considered a useful tool worldwide.

\section{References}

[1] Wolny A., Źróbek-Różańska A., Źróbek R., Piotrowski M., Frey J.: Development of Areas and Public Purpose Investments in Suburban Territories. Real Estate Management and Valuation, vol. 22, issue 2, 2014, pp. 86-97.

[2] van Hoof J., Kazak J.: Urban ageing. Indoor and Built Environment, vol. 27, issue 5, 2018, pp. 583-586.

[3] van Hoof J.; Kazak J.K., Perek-Białas J.M., Peek S.T.M.: The Challenges of Urban Ageing: Making Cities Age-Friendly in Europe. International Journal of Environmental Research and Public Health, vol. 15, 2018, 2473.

[4] Kiełkowska J., Tokarczyk-Dorociak K., Kazak J., Szewrański S., van Hoof J.: Urban Adaptation to Climate Change Plans and Policies - the Conceptual Framework of a Methodological Approach. Journal of Ecological Engineering, vol. 19, issue 2, 2018, pp. 50-62.

[5] Bazan-Krzywoszańska A., Mrówczyńska M., Skiba M., Stubecka M.: Sustainable Urban Development on the Example of the Housing Development of Zielona Góra (Poland), as a Response to the Climate Policy of the European Union. [in:] "Environmental Engineering" 10th International Conference, Vilnius Gediminas Technical University, Lithuania, 27-28 April 2017, 2017, article ID: enviro.2017.XXX. 
[6] Kajdanek K.: Newcomers vs. Old-Timers? Community, Cooperation and Conflict in the Post-Socialist Suburbs of Wrocław, Poland. [in:] Watt P., Smets P. (eds.), Mobilities and Neighbourhood Belonging in Cities and Suburbs, Palgrave Macmillan, London 2014, pp. 182-199.

[7] Foryś I.: Municipal Housing Resource Management System: Element of Polish City Management Strategy or Housing Policy?. IOP Conference Series: Materials Science and Engineering, vol. 471, 112078, 2019.

[8] Obwieszczenie Marszałka Sejmu Rzeczypospolitej Polskiej z dnia 11 maja 2017 r. w sprawie ogłoszenia jednolitego tekstu ustawy o planowaniu i zagospodarowaniu przestrzennym. Dz.U. 2017, poz. 1073 ze zm. [Announcement by the Speaker of the Sejm of the Republic of Poland of 11 May 2017 on the announcement of the consolidated text of the Act on spatial planning and development. Journal of Laws of 2017, item 1073, as amended].

[9] Stacherzak A., Hełdak M., Raszka B.: Planning Documents and Sustainable Development of a Commune in Poland. WIT Transactions on Ecology and the Environment, vol. 162, 2012, pp. 23-34.

[10] Bazan-Krzywoszańska A., Skiba M., Mrówczyńska M., Sztubecka M., Bazuń D., Kwiatkowski M.: Green energy in municipal planning documents. E3S Web of Conferences INFRAEKO 2018, vol. 45, 00006, 2018.

[11] Hełdak M., Płuciennik M.: Costs of Urbanisation in Poland, Based on the Example of Wroctaw. IOP Conference Series: Materials Science and Engineering, vol. 245, 072003, 2017.

[12] Foryś I., Cymerman J.: Imbalance in local revenues from property taxes in Poland versus local infrastructure expenditures. IOP Conference Series: Materials Science and Engineering, vol. 603, 022005, 2019.

[13] Bieda A.: Urban renewal and the value of real properties. Studia Regionalne i Lokalne, nr 3(69), 2017, pp. 5-28.

[14] Szewrański S., Kazak J., Szkaradkiewicz M., Sasik J.: Flood Risk Factors in Suburban Area in the Context of Climate Change Adaptation Policies - Case Study of Wrocław, Poland. Journal of Ecological Engineering, vol. 16 (2), 2015, pp. 13-18.

[15] Brunello A., Kamińska J., Marzano E., Montanari A., Sciavicco G., Turek T.: Assessing the Role of Temporal Information in Modelling Short-Term Air Pollution Effects Based on Traffic and Meteorological Conditions: A Case Study in Wroctaw. [in:] Welzer T. et al. (eds.), New Trends in Databases and Information Systems. ADBIS 2019. Communications in Computer and Information Science, vol. 1064, Springer, Cham 2019, pp. 463-474.

[16] Zonova Y., Migdał P., Roman A., Popiela-Pleban E., Opaliński S., Kowalska-Góralska M.: Oddziaływanie przemysłu miedziowego na zawartość srebra i niklu w glebie i roślinach miododajnych. Przemysł Chemiczny, t. 96, nr 9, 2017, pp. 1979-1981.

[17] Noszczyk T., Hernik J., Głowacka A., Taszakowski J.: Preventing and Resolving Social Dissatisfaction in Spatial Management in Rural Areas. Engineering for Rural Development, 2017, pp. 1057-1063. 
[18] Stuła T., Kazak J.: Spatial Absorbency Concept as a Decision Support System for Sustainable Local Development. IOP Conference Series: Materials Science and Engineering, vol. 471, issue 11, 112009, 2019.

[19] Noszczyk T.: Land Use Change Monitoring as a Task of Local Government Administration in Poland. Journal of Ecological Engineering, vol. 19, issue 1, 2018, pp. $170-176$.

[20] Dawidowicz A., Źróbek R.: Land Administration System for Sustainable Development - Case Study of Poland. Real Estate Management and Valuation, vol. 25, Issue 1, 2017, pp. 112-122.

[21] Kazak J., Szewrański S.: The Use of Geoinformation in Land Acquisition for Road Developments. Real Estate Management and Valuation, vol. 22, issue 1, 2014, pp. 32-38.

[22] Iwaniak A., Leszczuk M., Strzelecki M., Harvey F., Kaczmarek I.: A Novel Approach for Publishing Linked Open Geodata from National Registries with the Use of Semantically Annotated Context Dependent Web Page. ISPRS International Journal of Geo-Information, issue 6(8), 2017, pp. 252.

[23] Resolution of the Racibórz City Council No. XXXVIII/575/2009 of December 30, 2009. regarding adopting the Study of conditions and directions of spatial development of the city Racibórz.

[24] Resolution of the Gdańsk City Council No. LI/1506/18 of April 3, 2018. regarding adopting the Study of conditions and directions of spatial development of the city Gdańsk.

[25] Resolution of the City of Łódź Council No. LXIX/17536/18 of March 28, 2018. regarding adopting the Study of conditions and directions of spatial development of the city Łódź.

[26] Resolution of the Torun City Council No. 805/18 of January 25, 2018. regarding adopting the Study of conditions and directions of spatial development in the city of Torun.

[27] Resolution of the City Council of Kalisz No. XLVI/566/2017 of November 30, 2017. regarding adopting the Study of conditions and directions of spatial development of the city Kalisz.

[28] Przybyła K., Kachniarz M., Ramsey D.: The investment activity of cities in the context of their administrative status: A case study from Poland. Cities, vol. 97, 102505, 2020.

[29] Krajewski P., Solecka I.: Management System of Urban Landscape in Poland on the Example of Wroclaw in the Context of European Landscape Convention Implementation. IOP Conference Series: Materials Science and Engineering, vol. 471, 112035, 2019.

[30] Przybyłowicz A.: The Legal Position of Persons Dependent on Long-Term Care in the Republic of Poland. [in:] Becker U., Reinhard H.-J. (eds.), Long-Term Care in Europe, Springer International Publishing, Cham 2018, pp. 381-413. 
[31] Dąbrowska J., Kaczmarek H., Markowska J., Tyszkowski S., Kempa O., Gałęza M., Kucharczak-Moryl E., Moryl A.: Shore zone in protection of water quality in agricultural landscape - the Mściwojów Reservoir, southwestern Poland. Environmental Monitoring and Assessment, vol. 188, article number 467, 2016.

[32] Tokarczyk-Dorociak K., Kazak J., Szewrański S.: The Impact of a Large City on Land Use in Suburban Area - the Case of Wroctaw (Poland). Journal of Ecological Engineering, vol. 19, 2018, pp. 89-98.

[33] Jawecki B., Sobota M., Burszta-Adamiak E.: The influence of new legal regulations on the method of determining the amount of fees for discharging rain water and snow water to water. Ekonomia i Środowisko, nr 1, 2019, pp. 37-56.

[34] Trembecka A., Kwartnik-Pruc A.: Problems of Real Estate Management with Respect to Claims for Restitution of Expropriated Properties. Real Estate Management and Valuation, vol. 26, issue 3, pp. 105-112.

[35] Kazak J., Wang T., Szewrański S.: Analysis of Land Use Transformation Potential in Spatial Management. Real Estate Management and Valuation, vol. 23, issue 1, 2015, pp. 5-14.

[36] Szewrański S., Bochenkiewicz M., Kachniarz M., Kazak J.K., Sylla M., Świąder M., Tokarczyk-Dorociak K.: Location support system for energy clusters management at regional level. IOP Conference Series: Earth and Environmental Science, vol. 354, 012021, 2019.

[37] Wang T., Han Q., de Vries B.: SIRPSS - Sustainable Industrial Site Redevelopment Planning Support System. [in:] Dargam F., Delias P., Linden I., Mareschal B. (eds.), Decision Support Systems VIII: Sustainable Data-Driven and Evidence-Based Decision Support, Springer International Publishing, Cham 2018, pp. 3-14.

[38] Foryś I., Kazak J.: "Absorption" or "Carrying Capacity" of Areas - Assessment Methods on the Example of Detached Housing Real Estate. Real Estate Management and Valuation, vol. 27, issue 2, 2019, pp. 5-19.

[39] Świąder M.: The implementation of the concept of environmental carrying capacity into spatial management of cities. Management of Environmental Quality, vol. 29, issue 6, pp. 1059-1074.

[40] Przybyła K., Kulczyk-Dynowska A., Kachniarz M.: Quality of Life in the Regional Capitals of Poland. Journal of Economic Issues, vol. 48, issue 1, 2014, pp. 181-195.

[41] Furmankiewicz M., Campbell A.: From Single-Use Community Facilities Support to Integrated Sustainable Development: The Aims of Inter-Municipal Cooperation in Poland, 1990-2018. Sustainability, vol. 11 (21), 5890, 2019.

[42] Kazak J., van Hoof J.: Decision support systems for a sustainable management of the indoor and built environment. Indoor and Built Environment, vol. 27, issue 10, 2018, pp. 1303-1306. 
[43] Mrówczyńska M., Sztubecka M., Skiba M., Bazan-Krzywoszańska A., Bejga P.: The Use of Artificial Intelligence as a Tool Supporting Sustainable Development Local Policy. Sustainability, vol. 11(15), 4199, 2019.

[44] Figurska M., Wisniewski R.: Fundamental Analysis - Possiblity of Application on the Real Estate Market. Real Estate Management and Valuation, vol. 24, 2016, pp. 35-46.

\section{Ocena chłonności przestrzennej dla zrównoważonego zagospodarowania terenu}

Streszczenie: Zrównoważony rozwój użytkowania gruntów wymaga racjonalnego procesu podejmowania decyzji opartych na odpowiednich wzorcach zagospodarowania przestrzennego. Jednak proinwestycyjna polityka wielu gmin często prowadzi do powstawania dysproporcji pomiędzy popytem na tereny inwestycyjne a ich podaża, co oznacza, że rozwój przestrzenny nie jest realizowany w sposób zrównoważony. W celu uniknięcia sytuacji nadmiernej konsumpcji zasobów przestrzennych rząd centralny w Polsce wprowadził obowiązek oceny bilansu terenów, co obejmuje oszacowanie chłonności przestrzennej na poziomie lokalnego planowania przestrzennego. Celem tej pracy jest opracowanie koncepcji oceny chłonności przestrzennej. W celu wybrania najlepszych praktyk przeprowadzono przeglądy dokumentów dotyczących lokalnych polityk przestrzennych w Kaliszu, Łodzi, Toruniu i Gdańsku. Na podstawie przeprowadzonego przeglądu przedstawiono metodę oceny chłonności przestrzennej. Możliwość wykorzystania proponowanego rozwiązania przedstawiono na przykładzie gminy Racibórz. Zastosowanie metody pokazuje, jakiego rodzaju geoinformacja jest konieczna do przeprowadzenia procesu oceny. Wyniki obliczeń stanowią informację zwrotną jaką otrzymują władze lokalne. Praca została wykonana przy użyciu oprogramowania ArcGIS. Uzyskane wyniki mogą stanowić podstawę do dalszych wielowymiarowych analiz zrównoważonego planowania przestrzennego na poziomie lokalnym.

Słowa

kluczowe: chłonność, pojemność przestrzenna, planowanie przestrzenne, rozwój przestrzenny 